
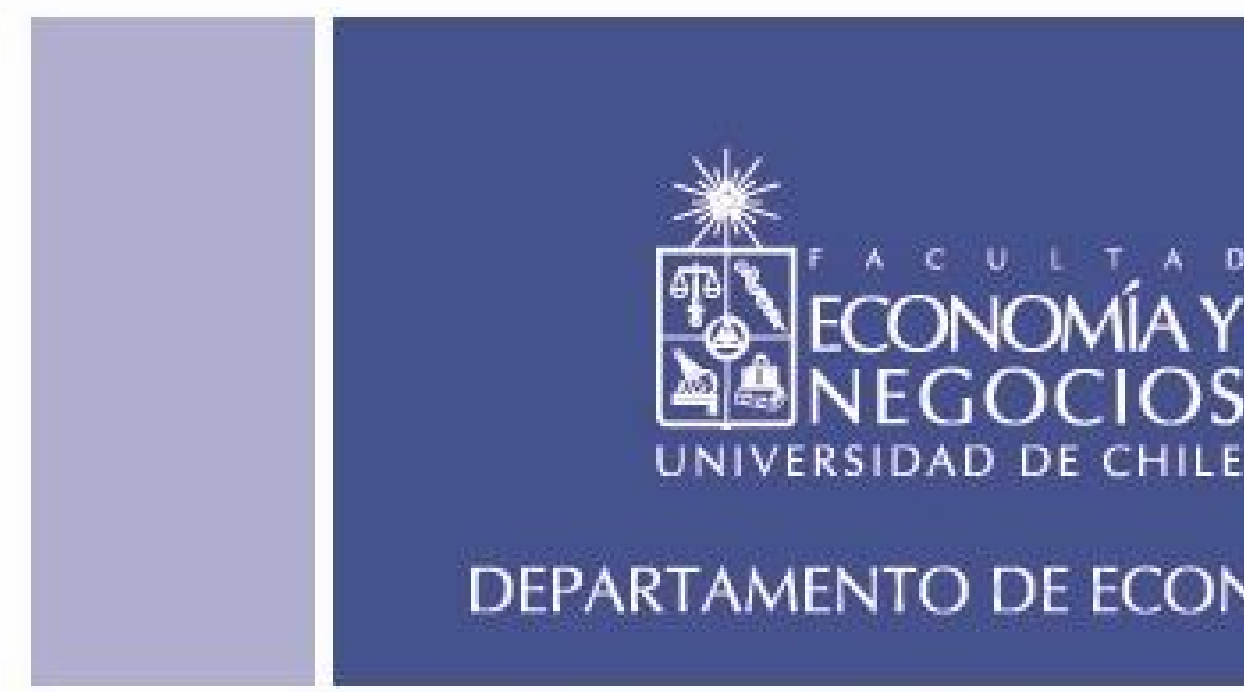

DEPARTAMENTO DE ECONOMÍA

\title{
SDT 295
}

\section{OVERREACTION IN CAPITAL FLOWS TO EMERGING MARKETS: BOOMS AND SUDDEN STOPS}

Autores: Manuel Agosin y Franklin Huaita

Santiago, abril 2009 


\title{
Serie Documentos de Trabajo \\ N 295
}

\section{Overreaction in Capital Flows to Emerging Markets: Booms and Sudden Stops}

\author{
Manuel Agosin ${ }^{1}$
}

\author{
Franklin Huaita ${ }^{2}$
}

\begin{abstract}
This paper applies the overreaction hypothesis of De Bondt and Thaler (1985), developed for stock price behaviour, to capital flows to emerging markets. We find that a surge in capital flows, or what we call a capital boom, can predict future sharp contractions in capital flows, or sudden stops. We use a large list of possible economic fundamentals as control variables, and the results show that the best predictor of a sudden stop is a preceding capital boom. Moreover, the probability of a country undergoing a sudden stop increases considerably with the length of the boom: this probability more than doubles when the boom is three years old, and rises by three to four times when the boom lasts for four years. These results are interesting for two reasons. In the first place, they contradict previous studies that emphasize worsening fundamentals as the ultimate cause of a sudden stop. Second, they are of policy interest because of the enormous negative impacts that sudden stops have on the real economy
\end{abstract}

JEL Classification:

F30, F32, F39

Key Words:

Capital flows, Emerging Markets, Sudden Stops, Overreaction

1 Departamento de Economía, Universidad de Chile. managosin@fen.uchile.cl 2 Departamento de Economía, Universidad de Chile. frhuaita@fen.uchile.cl 


\section{Introduction}

Informal claims of overreaction in financial markets arise more frequently than they are admitted by economists and analysts, who feel more comfortable anchoring stock price movements to informed expectations about future fundamentals. However, in a seminal work De Bondt and Thaler (1985) evaluate what they call "overreaction" in the stock market and prove that, as is the case with many other human activities, financial markets show an excessive reaction to new information or unexpected events. One of their main conclusions is that a pronounced reversion in prices (negative returns) can be predicted by the observation of extreme preceding positive returns; in other words, an upward overreaction subsequently calls forth a dramatic downward adjustment.

An important aspect of this literature is the identification of an overreaction, which is related to psychological factors that push a price much beyond what would be determined by fundamental factors. Consequently, examples of markets with frequent overreaction behaviour are those showing excess volatility. Such is the case of capital flows to emerging markets, where an unexplained volatility has been found. In a recent paper, Broner and Rigobon (2006) showed that capital flows to emerging markets are more volatile than those to developed countries. Using GDP per capita, inflation rates, real depreciation of exchange rates, terms of trade and interest rates for a set of emerging countries, the standard deviation of the error from panel estimations was greater than the error from a panel using data for developed countries by more than 60 percent. This standard deviation was significantly reduced using own lags of capital flows and contagion variables.

Our approach is different. We focus on the predictive power of a capital flow bonanza on subsequent and sharp reversions of capital flows, labelled sudden stops in recent literature, and consider this pattern as an example of overreaction. We define episodes of large capital flows to emerging markets, which we call capital booms, as those that are larger than a standard deviation above the historical mean and represent 
at least five percentage points of GDP. Using the definition of sudden stops by Guidotti et al (2004), we define periods of abrupt reversions, or sudden stops, as those when capital inflows decline by more than a standard deviation of their average increase during the sample period and when that decline is at least five percentage points of GDP. Similarly to the findings for stock prices, our results indicate that a capital boom period is a good predictor of a subsequent sudden stop. Moreover, we find that the probability of a sudden stop increases dramatically the longer the preceding capital boom.

In our approach, emerging markets should be seen as an asset class for financial markets. ${ }^{3}$ This view has been confirmed by Leijonhufvud (2007), who shows that financial institutions have separate business units that manage profit and loss targets for their investments in emerging markets. Leijonhufvud stresses that this organizational form is responsible for the concentration of risk in emerging markets and the consequent formation of bubbles in asset prices. In addition, compensation systems "which link annual bonus payments to the amount of net income an employee has generated for the firm or its clients in a given year directly encourage employees to focus on short-term income opportunities" (Leijonhufvud, 2007). These ideas are lent credence by Kaminsky et al (2004). Using monthly and quarterly data, they showed the existence of chartist strategies (buy winners and sell losers) and contagion trading in mutual funds dedicated to Latin American assets. These strategies proved stronger during crises.

In this paper, we use the financial account of the balance of payments (excluding reserve movements) as our closest measure of net capital flows. With a multivariate analysis of the probability of suffering a sudden stop, we test the relevance of prior capital booms. A capital boom year is a period dominated by short run chartist strategies, as described previously. We find that the probability of the capital boom

\footnotetext{
${ }^{3}$ This is application of Kindleberger's (2005) model of financial crises, where agents are prone to manias, which eventually give way to panics, in markets for specific asset classes.
} 
continuing one extra year is significant in countries that have experienced a capital boom the year before, and that this probability is very similar to the probability of suffering a sudden stop. However, as the capital boom lengthens, the probability of a subsequent sudden stop rises markedly, while the probability that the capital boom will continue drops to zero.

In contrast to other studies such as those by Edwards (2007), Calvo at al (2004) or Cavallo and Frankel (2004), who attribute to domestic variables the cause of sudden stops, our results indicate that sudden stops are downward overreactions to sharp preceding overreaction periods. This does not mean that fundamentals are unimportant in preventing a sudden stop episode. In fact, we postulate that large capital inflows can bring about an endogenous change in some macroeconomic variables - e. g., a deterioration of the current account deficit, a sharp appreciation of the real exchange rate, an excessive rise in bank credit to the private non-bank sector, or a progressive mismatch in the balance sheets of firms and banks that borrow in foreign currency. This deterioration of fundamentals caused by large capital booms that cannot be easily absorbed by economies with small financial sectors is what eventually triggers a massive withdrawal of capital. $^{4}$ Many of these variables reflecting domestic fundamentals turn out not to be robust in their predictive power and are indeed rendered insignificant when measures of preceding capital booms are incorporated into the econometric analysis. This leads us to posit that large capital inflows are the best predictor of sudden stops in emerging economies.

The rest of the paper is organized as follows. The next section sets forth the definitions of capital boom and sudden stop episodes. Section 3 describes the methodological analysis. Section 4 and Section 5 present our main results and some

\footnotetext{
${ }^{4}$ A recent discussion of capital flow bonanzas and sudden stops can be found in Reinhart and Reinhart (2008), who arrive at similar conclusions as those of this paper. However, they use the current account as a measure of capital movements, while we use the net financial account. These two measures differ, of course, as capital inflows, for example, could be partly absorbed as reserves and not only go to finance the current account. In contrast to Reinhart and Reinhart, who use mostly descriptive statistics, we try to test our hypothesis with a multivariate econometric model of sudden stops.
} 
robustness exercises, respectively. Finally, Section 6 provides some discussion and concluding remarks.

\section{Definition of Boom and Sudden Stop Periods}

We use annual data for 42 emerging economies in the period 1976 - 2003, which includes all of the boom and sudden stop years in recent economic history (with the exception of the booms leading to the current world financial crisis). Thus the 1976-82 period corresponds to the boom years identified with the recycling of the oil producers' surpluses; $1983-89$ coincides with the Latin American debt crisis; $1990-97$ is another period of capital boom and financial innovation in lending to and investing in emerging economies; and $1998-2003$ is the period after the Asian and Russian financial crises struck. The complete list of countries is shown in the appendix.

\subsection{Boom Episodes}

We define a year of capital boom when the financial account of the balance of payments is a standard deviation above its mean and is at least $5 \%$ of the GDP. Thus, there is a capital boom in the year $\mathrm{t}$ when $F_{i t}=1$ according to the following rule:

$F F_{i t}=\left\{\begin{array}{l}1 \text { if } F_{i t}>\bar{F}_{t}+\sigma_{F_{i}} \text { and } \frac{F_{i t}}{G D P_{i t}}>5 \% \\ 0 \text { otherwise }\end{array}\right.$

where $F_{i t}$ is the value of the financial account of country $i$ in year $t$ (current US dollars deflated by the US consumer price index), $\bar{F}_{i}$ is its mean for the entire period and $\sigma_{F_{i}}$ is its standard deviation. By using as our definition of capital boom requiring that the capital flows are one standard deviation above the mean we assure the unusual character of this episode. The normalization by GDP is used in order to detect surges that represent a large deviation with respect to the country's economic size. We prefer to use the level of capital flows rather than their annual change because our objective 
is to test for the impact of large levels, not large changes in capital inflows. In the 19762003 period, there are 152 capital booms (so defined) in the 42 countries in the sample. The appendix lists these episodes.

\subsection{Sudden Stop Episodes}

Following Guidotti et al (2004), we identify a sudden stop of capital flows when the annual change in the financial account is one standard deviation below its mean and is larger than $5 \%$ of GDP. Concretely, a country will suffer a sudden stop when $S S_{i t}=1$ according to the following rule:

$S S_{i t}\left\{\begin{array}{l}1 \text { if } \Delta F_{i t}<\overline{\Delta F_{i}}-\sigma_{\Delta F_{i}} \text { and }\left|\frac{\Delta F_{i t}}{G D P_{i t}}\right| \geq 5 \%, \text { whenever } F_{i t-1}>0 \text { and } F F_{i t}=0 \\ 0 \text { otherwise }\end{array}\right.$

where $\Delta F_{i t}$ is the change in the financial account of country $i$ in year $t, \overline{\Delta F_{i}}$ is the average change in the financial account of country $i$ over the sample period and $\sigma_{\Delta F_{i}}$ is its standard deviation. In the case of sudden stops, we are interested not in the absolute value of capital flows but in a significant decline from the preceding year. Again, as with capital booms, the joint condition applied to classify an event as a sudden stop works in the same fashion. Thus, countries with little volatility in capital flows can experience episodes with falling capital inflows (or with capital outflows) which do not have major impacts on their economies; by requiring that the contraction be a certain percentage of GDP, we attempt to guarantee that they are important for the countries experiencing it.

Since our interest is to identify the start of a contraction in capital inflow, whenever a sudden stop in a particular year is followed by another sudden stop the following year, only the first contraction will be considered to be a sudden stop. As noted in definition (2), we discard episodes which are both sudden stops and capital booms, as per definition (1). In our sample, we found 74 episodes that qualify for 
sudden stops ( $7 \%$ of the sample). The annual distribution of sudden stops is shown in the appendix.

A view of these episodes is shown in Figure 1. The horizontal line is placed a standard deviation above the mean for each country. The shadowed region shows the drop in capital flows that corresponds to a sudden stop. These examples suggest that sudden stops are sharp adjustments after periods of consecutive booms.

\section{[Insert Figure 1]}

In Table 1 we show the average contraction of capital flows as a share of GDP occurring two years after a three-year period of capital boom. This contraction is always higher than after a three-year period of positive capital inflows in tranquil times ${ }^{5}$ and significantly different for all the geographical regions considered with the exception of emerging Europe. Another relevant characteristic is that the average growth rate of GDP two years after a three-year boom is considerably lower than in countries with positive capital inflows for three years but without a boom. Again, this difference is significant for all regional groups of countries with the exception of emerging Europe.

\section{[Insert Table 1]}

\section{Multivariate Probit Analysis}

Being $\Phi$ the standard normal distribution, we estimate a panel probit with heterogeneous unobserved effects. For the boom episodes we estimate the following equation:

$$
\begin{aligned}
& \operatorname{Pr}\left(F F_{i t}=1 / F F_{i t-1}, \operatorname{ContFF}_{i t}, N o n F D I_{i t-1}, \mathbf{X}_{i t-1}, c_{i}\right)= \\
& \quad \Phi\left(\gamma_{f} F F_{i t-1}+\gamma_{c} \operatorname{ContFF}_{i t}+\gamma_{n f} N o n F D I_{i t-1}+\mathbf{X}_{i t-1} \beta+c_{i}\right)
\end{aligned}
$$

where ContFF (boom contagion) is a binary contagion variable taking value 1 when the number of boom episodes in a particular year and the year before in other countries of the sample exceeds twice the average annual number of booms. NonFDI is non-FDI

\footnotetext{
${ }^{5}$ Observations of "tranquil" periods for countries experiencing a prior sudden stop are excluded.
} 
flows in the financial account as a share of GDP, $\boldsymbol{X}$ is a matrix of control variables and $c$ is the unobserved country specific effect.

The variable FF lagged one period describes the overreaction (or feedback) effect in euphoric phases. According to Kindleberger (2005), the optimism of investors strengthens during periods of bonanza because of the knowledge that investors have of what other investors are doing. Thus large investments tend to be contagious and attract other investments, which generate a boom that can be self-sustaining for some time. The inclusion of this variable is meant to reflect the chartist strategies that are used by institutional and other investors when capital flows to a particular country or group of countries are large. The inclusion of NonFDI is congruent with our theoretical support because these kinds of flows generally have a shorter horizon than FDI and are susceptible to reversal as investors acquire new information. FDI is much less prone to chartist strategies, has much longer time horizons, and is not so easily reversed. As can be seen in Figure 2, non-FDI flows show an increasing trend in years prior to a sudden stop and drop sharply during these events. ${ }^{6}$ By contrast, FDI flows exhibit neither surges nor sudden stops around the years identified as being characterized by a sudden stop.

\section{[Insert Figure 2]}

Matrix $\mathrm{X}$ includes variables that could be interpreted as determinants of capital flows. ${ }^{7}$ These are the GDP growth $(R G D P)$, the change in terms of trade $(T T)$, the ratio of external debt to exports $(E D / X)$, and the current account deficit as a share of GDP $(C A D)$. Other variables included refer to domestic or external conditions. The real foreign interest rate $(R f)$ and the rate of growth of $G 7$ countries (G7gdp) reflect external conditions affecting capital flows, and the real domestic interest rate $(R d)$ and the fiscal deficit (Gov_Def) are domestic fundamentals.

\footnotetext{
${ }^{6}$ This is consistent with findings of Levchenko and Mauro (2006), who decompose the flows around sudden stop episodes and show that the most volatile are non-FDI flows.

${ }^{7}$ All variables are from International Monetary Fund, International Financial Statistics; and World Bank, World Development Indicators. Exact variable definitions are given in the appendix.
} 
We follow a similar strategy to estimate the probability of suffering a sudden stop:

$$
\begin{aligned}
\operatorname{Pr}\left(S S_{i t}=1 / F F_{i t-1}, \text { ContSS }_{i t},\right. & N_{\left.o n F D I_{i t-1}, \mathbf{X}_{i t-1}, c_{i}\right)=} \\
& \Phi\left(\gamma_{f} F F_{i t-1}+\gamma_{c} \operatorname{ContSS}_{i t}+\gamma_{n f} N_{o n F D I} I_{i t-1}+\mathbf{X}_{i t-1} \beta+c_{i}\right)
\end{aligned}
$$

This time $F F_{t-1}$ is a proxy for an overreaction that is in need of correction: a period of bonanza is not going to persist forever. In a financial market with many heterogeneous agents, some of them are aware that the high levels of capital inflows are related more to feedbacks from other investors than with economic fundamentals. New information can arise (such as an endogenous worsening of one or more fundamentals), provoking a sharp adjustment. These periods are typically dominated by non-FDI flows; therefore we include this variable in the empirical analysis. As in equation (3), ContSS is a binary variable taking value 1 when the number of sudden stops in a particular year and the year before in other countries of the sample exceeds twice the average annual number of sudden stops. ${ }^{8}$ As shown in the next section, contagion can raise the probability of experiencing a sudden stop.

In matrix $\boldsymbol{X}$ there are variables that have been used in the literature on balanceof-payment crises and determinants of sudden stops. The most used and successful variable has been the current account deficit, $C A D$. Furthermore, we use an indicator of banking crises (bankcrises) with data from Caprio and Kinglebiel (2003) and another of exchange rate rigidity $(E X R)$ from Levy-Yeyati and Sturzenegger (2005) in order to test the hypothesis that sudden stops are more likely in countries with fixed rather than flexible exchange rate regimes. Large levels of external debt to exports $(E D / X)$ may also raise the probability of a sudden stop. Other variables found significant in other studies are liability dollarization (dollarization) and economic openness (openness). ${ }^{9}$ Both are used in our estimations. In addition, in some specifications we use real

\footnotetext{
${ }^{8}$ For this variable we consider the total number of sudden stop without eliminating a second year of sudden stop as in equation (2). For example, we consider a sudden stop in 1994 and 1995 in Mexico.

${ }^{9}$ See Calvo et al (2004) and Cavallo and Frankel (2004), respectively.
} 
exchange rate depreciation $(R E R)$, the ratio of $\mathrm{M} 2$ to GDP $(M 2 / G D P)$, the change in terms of trade (TT) and the change of reserves (Reserves) to control for possible signals that may generate a stampede by investors. As in the model of capital booms, external variables (Rf, G7gr) and domestic fundamentals (Rd, Gov_Def) are also included.

To estimate (3) and (4) we use random effects and, following Wooldridge (2002), we report the average marginal effect given by:

$$
\frac{\partial E[P(y=1 / \mathbf{X}, c) / c]}{\partial X_{j}}=\frac{\partial \Phi(\mathbf{X} \beta / \sigma)}{\partial X_{j}}=\left(\beta_{j} / \sigma\right) \phi(\mathbf{X} \beta / \sigma)
$$

where for notational simplicity we have suppressed both cross-section and time-series indicators; $y$ indicates the endogenous variable (FF or $S S$ ) and matrix $\boldsymbol{X}$ includes all variables in the right hand side of (3) and (4). Variable $c$ has a conditional distribution $\mathrm{c} / \mathbf{X} \sim \mathrm{N}\left(0, \tau^{2}\right)$ so that $\sigma=\left(1+\tau^{2}\right)^{1 / 2}$. $\phi$ represents the standard normal density.

Since the model of equation (3) is a dynamic panel, we require additional assumptions. In order to report consistent estimators, we cannot use the first difference of the dependent variable - a very popular procedure in linear models because the standard normal distribution is a highly nonlinear function. We follow Wooldridge (2000 and 2002) and propose the following distribution for $c_{i}$ :

$h\left(c_{i} / y_{i 0}, \mathbf{X}_{i}, \delta\right)=\psi+\xi_{0} y_{i 0}+\overline{\mathbf{X}}_{i} \xi+a_{i}$ con $a_{i} \sim N\left(0, \sigma_{a}^{2}\right)$

where $i$ indicates cross-section units, $y_{i 0}$ is the initial value of the dependent variable, and $\overline{\mathbf{X}}_{i}$ is a matrix with the average value for each explanatory variable. Including assumption (6) in the estimation of equation (3) implies adding to the estimating equation the average value of the explanatory variables and the initial value of the dependent variable. ${ }^{10}$

\footnotetext{
${ }^{10}$ In the results, we do not report the values of the coefficients attached to these variables.
} 


\section{Main Results}

Table 2 shows the results for the estimation of equation (3). In column (1) all the variables employed are significant at least at the $5 \%$ level and have the expected signs. Our lagged variable of capital booms is very significant and shows the highest marginal effect. If the previous year the economy was undergoing a boom episode the probability that this boom will persist the next year increases by $13 \%$. This result is congruent with the feedback forces identified by Kindleberger and the strategies and transmission mechanisms explained in the behavioral finance literature. ${ }^{11}$

Contagion from other countries is another relevant variable, raising the probability of a boom episode by $6 \%$. Furthermore, large non-FDI flows, a high growth rate of GDP and a positive terms-of-trade shock raise the probability of a capital boom episode the next year although their marginal effects are small. The external debt to exports ratio emerges as an important variable discouraging booms and, unexpectedly, the current account deficit has a positive sign. This result seems to indicate that the current account deficit works as a proxy for capital flows to the country.

In column (2) of Table 2 we add external and domestic variables. As expected, falls in external interest rate and in the growth rate of G7 countries increase the probability of a capital boom, whereas wider fiscal deficits reduce it. Terms-of-trade and non-FDI flows are not robust to the inclusion of other relevant variables.

[Insert Table 2]

Table 3 shows the results for the estimation of equation (4). We progressively include variables in columns and exclude others to avoid inference problems from irrelevant variables. A capital boom in the preceding period is a strong predictor of a sudden stop, its effect is the highest (increases in the probability of a sudden stop of around $9 \%$, and it is robust to the inclusion of other variables. This result is interesting because it is achieved conditioning to the action of other variables or fundamentals that can be affected by the capital flow bonanzas. Therefore, it extends the hypothesis of

${ }^{11}$ See Shiller (2003) or Barberis and Thaler (2003) for a review of this literature. 
adjustment caused by a previous upward overreaction period in capital flows to emerging markets.

Other variables that turn out to be significant and robust are: contagion, non-FDI flows, the current account deficit, and the external-debt-to-exports ratio. International contagion raises the probability of a sudden stop by about $3 \%$. All significant variables have the expected signs.

[Insert Table 3]

\subsection{A longer capital-boom period}

The probability of a capital boom does not rise significantly as the boom lengthens; however, the probability of suffering a sudden stop increases dramatically with the length of the preceding boom. Table 4 summarizes the marginal effects that are significant for similar specifications as those in Table 3, but lengthening the boom period by one year from one column to the next. Thus columns (1) and (4) show the results of estimating equation (3) and (4), respectively, with a two-year boom period; in columns (2) and (5) the boom is lengthened to three years; and columns (3) and (6) shows the results for a four-year boom period. The results support the hypothesis that corrections to overreactions will become increasingly likely the longer the overreaction has been going on. If a capital boom has continued for a period of four years, the probability of a sudden stop rises to a very large $27 \%$.

\section{[Insert Table 4]}

\subsection{Sub-sample 1990-2003}

As can be seen in the appendix, after 1982 and before 1991 there were very few years of large capital inflows in the emerging world. In 1991, capital surges begin to take place in Asia and Latin America. Table 5 shows estimations for a sub-sample including only the period 1990-2003 in a subset of countries: Argentina, Bolivia, Brazil, Chile, 
China, Colombia, Ecuador, India, Indonesia, Korea, Malaysia, Mexico, Pakistan, Paraguay, Peru, Philippines, Thailand and Uruguay.

\section{[Insert Table 5]}

The probit estimations for capital boom episodes show that the only relevant domestic variables that raise their probability are RGDP and $C A D$. On the other hand, the results for sudden stop determinants confirm the evidence of Table 4 . When the boom period lengthens, the probability of a country undergoing a sudden stop rises. Limiting the sample to these countries and this latter period also raises the importance of contagion. The probability of a sudden stop as a result of contagion rises from the original 3\% shown in Table 4 to the $6-15 \%$ estimated in the runs reported in Table 5.

\section{Some Robustness Tests}

In order to test the robustness of the results, we change the threshold of $5 \%$ of GDP in equations (1) and (2) to $3 \%$ and $7 \%$ thresholds, respectively. Furthermore, following Faucette et al (2005) and Rothenberg and Warnock (2006), we use only gross flows (liabilities) instead of net flows to construct the capital boom and sudden stop periods. The results are reported in Tables 6 and 7. Finally, Table 7 shows an additional definition for sudden stops. We name this definition SSgdp and it requires, in addition to the conditions specified in equation (2), a fall in GDP during the year of the sudden stop or a year later. SSgdp reflects capital flight episodes that have had a large effect on the real sector.

Table 6 reports the marginal effects of probit estimations for capital boom episodes. The effect of a prior capital boom is similar to that shown in Table 2 and very significant; therefore, our prior conclusions regarding the sources of a capital boom still hold. Some variables such as $R f, G 7 g d p$ and $R d$ are not relevant when we define a more extreme capital boom episode; by contrast, the fiscal deficit, Gov_Def, becomes significant only when the threshold for booms is raised. As shown in the last column of Table 6, contagion and non-FDI flows are not significant determinants in extreme boom 
episodes, but they are significant when we use gross rather than net flows. Gross flows seem to be affected by overall growth in developed countries as well: a drop in the rate of growth in the G7 countries raises the probability of a capital boom in emerging markets.

\section{[Insert Table 6]}

Table 7 shows that our main variables are still significant using different definitions of sudden stops, supporting our conclusions described in the previous section. The prior boom of capital flows and its composition are very important in predicting a sudden stop. International contagion helps to account for a sudden stop episode, although it loses its relevance when a more extreme fall is required or when gross flows are used instead of net flows. The domestic variable that is important in every case is the current account deficit (CAD), supporting previous studies on the subject.

New variables appear to be significant in a sudden stop with a sharper decline in capital inflows. These include liability dollarization, the change in reserves, and the exchange rate regime. With the exception of the exchange rate regime, all show the expected sign. ${ }^{12}$ The capital boom, international contagion, and non-FDI flows are robust in predicting a sudden stop with negative real effects on GDP growth, SSgdp. An increase in external-debt-to-exports ratio, and not just in the current account deficit, is a domestic signal that could generate a reversion in capital flows. In one run, rising liability dollarization and increases in the foreign real interest rate significantly raise the probability of SSgdp. Unexpectedly, increases in domestic real interest rates have a positive impact on SSgdp, rather than dampening capital outflows. This result could be

\footnotetext{
${ }^{12}$ The negative sign of EXR in Table 7 indicates that a more rigid regime reduces the probability of suffering an extreme sudden stop, which is contrary to the conventional view. However, this can be an ambiguous result. We use the 1-5 classification of regimes of Levy-Yeyati and Sturzennegger (2005). In this classification, a floating regime has the least episodes of sudden stops; however, their number is not very different from those of other regimes; the maximum number of sudden stops is not associated with fixed exchange rate regimes.
} 
indicating that investors, faced with very adverse domestic conditions, view higher domestic interest rates as a symptom of further trouble down the road.

[Insert Table 7]

As a capital boom lengthens, the likelihood of a sudden stop rises even more sharply when the sudden stop is defined to be accompanied by a fall in GDP. As shown in Table 8, the probability of a sudden stop with a fall in GDP increases to $35 \%$ when a boom has gone on for a period of four years.

[Insert Table 8]

Another robustness test was undertaken using the early-warning-signal literature, as in Kaminsky et al (1998). The capital boom indicator may work as a signal, and the fact that it is a binary variable may enhance its importance in the probit estimations as compared to other explanatory variables, which are measured in a continuous way. For this reason, we take the current account deficit (the most robust domestic variable in previous estimations) and create a signal akin to the binary capital boom variable of equation (1), naming it $S 1 C A D$. In addition, we create another indicator based on the percentile of the current account deficit that minimizes the noiseto-signal ratio, as calculated in Kaminsky et al (1998). This optimal threshold is the highest fifth percentile; in other words, the largest fifth-percentile current account deficit minimizes this noise-signal ratio. ${ }^{13}$ We name this variable S2CAD.

Tables 9 and 10 show the results of probit estimations for both indicators of the current account deficit. We use three definitions of sudden stop: SS, SSgdp, and SSgross. Tables 9 and 10 indicate that including these indicators does not add relevant information to the one yielded by the capital boom variable, contagion, nonFDI

\footnotetext{
${ }^{13}$ This threshold looks for balancing the risk of having a wrong signal when a crisis does not take place with the risk of having no signal when a crisis does occur. The threshold is chosen to minimize $\mathrm{B} /(\mathrm{A}+\mathrm{B}) / \mathrm{D} /(\mathrm{C}+\mathrm{D})$, according to the following chart:
}

\begin{tabular}{|cc|cc|}
\hline & & \multicolumn{2}{|c|}{ Signal $_{\text {t-1 }}$} \\
& & No & Yes \\
\hline SS $_{\mathbf{t}}$ & No & A & B \\
& Yes & C & D \\
\hline
\end{tabular}


flows, the current account deficit as a share of GDP measured in a continuous way, and the external debt to exports ratio. In some cases when these indicators replace the continuous current account deficit variable, they show significant marginal effects, but these effects are lower than those associated with the capital boom variable.

\section{[Insert Table 9] \\ [Insert Table 10]}

Finally, we use the two-step procedure of Rivers and Vuong (1988) to discard any endogeneity problems that may remain between capital booms and subsequent sudden stops, even in spite of the fact that the capital boom variable is lagged one period in the equations explaining sudden stops. This test consists in including the errors of the estimation of the equation for capital booms in the estimation of the equation for sudden stops and testing for their significance. Table 11 shows the results obtained by including the residuals of the estimation of the equation reported in Table 2 in the specifications of the equations reported in Table 3. The results show that it is not possible to reject the null that the errors are equal to zero; in other words, there is no evidence that both capital surges and sudden stops are determined simultaneously.

[Insert Table 11]

\section{Discussion and Concluding Remarks}

There is a large and growing literature on what triggers a sharp contraction in capital flows to emerging markets. The current account deficit, liability dollarization, or excessive credit expansion are some of the variables that figure prominently in this literature. However, sudden stops have not been seen as a consequence of a previous period of overreaction in international financial markets. Capital booms are episodes of excessive enthusiasm that are unwarranted by fundamentals. They also show in a very graphic way that that chartist strategies rather than strategies based on future expectations of fundamentals dominate financial markets. In this sense, a capital boom will almost inevitably lead eventually to a sharp and sudden contraction. This 
means that deteriorating fundamentals are not always necessary to trigger a reversion of positive expectations; rather, it can be a rumor that disheartens the apparent optimism in a particular country, or international contagion that has little or no relationship with domestic conditions. An alternative explanation is that large capital inflows that are no easily (and productively) absorbed into the domestic economy induce a deterioration in one or more fundamentals, which functions as a negative signal to investors. Recent studies of herd behavioral in financial markets show that periods of overoptimism are fragile and can be suddenly reversed when participants face new information. Our application to capital flows to emerging markets confirms the overreaction hypothesis and its predictive power.

Using other arguments of behavioral finance, one can predict that the reversion of capital inflows will be sharper and shorter than the preceding bonanza. One example of such analyses is the loss-aversion hypothesis of Kahneman and Tversky (1979): faced with possible losses, investors will unload emerging market assets more quickly than they accumulated them during the boom. Unambiguously, if the recipient country faces a deterioration of its fundamentals, the probability of a quick reversion in capital flows can be very high.

What are the policy implications of our analysis? Clearly, emerging countries contemplating integration into international financial markets should take into account that they may face a new source of volatility and should tread carefully in this new world. 


\section{References}

Barberis, N., and Thaler, R., 2003. A Survey of Behavioral Finance. In: Handbook of the Economics of Finance, edited by G.M. Constantinides, M. Harris y R. Stulz, Chapter 18.

Benartzi, S., and Thaler, R., 1995. Myopic Loss Aversion and The Equity Premium Puzzle. Quarterly Journal of Economics 110, pag 73-92

Broner, F. A., and Rigobón, R., 2006. Why are capital flows so much more volatile in emerging than in developed countries? External vulnerability and preventive policies. Eds. R. J. Caballero, C. Calderón, and L. F. Céspedes. Central Bank of Chile. Santiago, 15-39.

Calvo, G, Izquierdo, A., and Mejía, L. F., 2004. On the empirics of sudden stops: the relevance of balance-sheet effects. NBER Working Paper 10520. Cambridge, MA.

Caprio, G., and Klingebiel D., 2003. Episodes of systematic and borderline financial crises. Working Paper, World Bank.

Cavallo, E., and Frankel, J., 2004. Does openness to trade make countries more vulnerable to sudden stops, or less? Using gravity to establish causality. NBER Working Paper N. 10957. Cambridge, MA.

De Bont, and W. Thaler, R., 1985. Does Stock Market Overreact?. Journal of Finance. Vol XL, №3. pag 793-805

Edwards, S., 2007. Capital controls, Capital Flow Contractions and Macroeconomic Vulnerability. Journal of International Money and Finance (26), 814-840

Faucette, E. J., Rothenberg, A. D., and Warnock, F., 2005. Outflows-induced sudden stops. The Journal of Policy Reform. Vol. 8, No. 2, 119-129.

Guidotti, P., Sturzenegger, F., and Villar, A., 2004. On the consequences of sudden stops. Economía. Vol. 4, No. 2, 1-44.

Kaminsky, G., Lizondo, S., Reinhart, C., 1998. "Leading Indicators of Currency Crises". IMF Staff Papers 45 (March)

Kaminsky, G., and Reinhart, C., 1999. The twin crises: the causes of banking and balance-of-payments problems. American Economic Review. Vol 89, No. 3, 473-500.

Kaminsky, G., Lyons, R. K., and Schmukler, S., 2004. Managers, Investors, and Crises: Mutual Fund Strategies in Emerging Markets. Journal of International Economics 64, 113-134.

Kahneman, D. Tversky, A., 1979 Prospect Theory: An Analysis of Decision Under Risk. Econometrica, Vol 47, No. 2. 263-291.

Kindleberger, C. P. 2005. With R. Aliber. Manias, Panics, and Crashes, A History of Financial Crises. Wiley, 2005.

Leijonhufvud, C., 2007. Financial globalisation and emerging markets volatility. The World Economy. December, 1817-1842. 
Levchenko, A., and Mauro, P., 2006. Do some forms of financial flows help protect from sudden stops? IMF Working Paper WP/06/202. Washington, D.C. September.

Levy-Yeyati, E., and Sturzenegger, F., 2005. Classifying exchange rate regimes: deeds vs. words. European Economic Review. 49, 1603-1635.

López-Mejía, A., 1999. Large Capital Flows: A Survey of the Causes, Consequences, and Policy Options. IMF Working Paper 99/17.

Reinhart, C., and Reinhart, V., 2008. Capital Flow Bonanzas: An Encompassing View of the Past and Present. NBER Working Paper № 14321

Rivers, D. and Vuong, Q. H., 1988. Limited Information Estimators and Exogeneity Tests for Simultaneous Probit Models. Journal of Econometrics Vol. 39, No. 3, 347366

Rothenberg, D. A., Warnock, F. E., 2006. Sudden Flight and True Sudden Stops. Institute for International Integration Studies, Discussion Paper № 187

Shiller, R. J., 2003. From efficient markets theory to behavioral finance. Journal of Economic Perspectives. Vol. 17, No. 1, Winter 2003, 83-104.

Wooldridge, J., 2000. "The Initial Conditions Problem in Dynamic, Nonlinear Panel Data Models with Unobserved Heterogeneity". Mimeo, Michigan State University.

Wooldridge, J., 2002. Econometric Analysis of Cross Section and Panel Data. The MIT Press 
Figure 1: Booms and sudden stops in capital flows

(1)

Note: millions of 2000 US dollars. 
Table 1: Average change in the financial account (\% of GDP) and GDP growth two years after a period of three-year capital boom, compared with the same variables in countries that did not experience a capital boom

\begin{tabular}{l|cc|ccc}
\hline & \multicolumn{2}{|c|}{ Three years with boom } & \multicolumn{2}{|c}{ Three years without } \\
Emerging country region & $\Delta$ F/GDP & $\Delta$ GDP/GDP & $\Delta$ F/GDP & $\Delta$ GDP/GDP \\
\hline $\begin{array}{l}\text { South America and } \\
\text { Mexico }\end{array}$ & $-3.9^{*}(11)$ & $-1.6^{*}(11)$ & $-1.0(68)$ & $2.2(68)$ \\
Central America & & & & \\
Asia & $-5.0^{*}(6)$ & $-0.4^{*}(6)$ & $0.6(56)$ & $3.6(56)$ \\
Africa & $-7.7^{*}(5)$ & $1.6^{*}(5)$ & $-0.0(131)$ & $5.7(132)$ \\
Europe & $-9.4^{*}(7)$ & $1.9^{*}(7)$ & $-0.5(56)$ & $4.0(56)$ \\
\hline
\end{tabular}

${ }^{a}$ Excluding three years after sudden stops. Number of episodes shown in parenthesis. "Difference is significant at $5 \%$. 
Figure 2: FDI and non-FDI flows around sudden stops

(Average flows to GDP ratios)

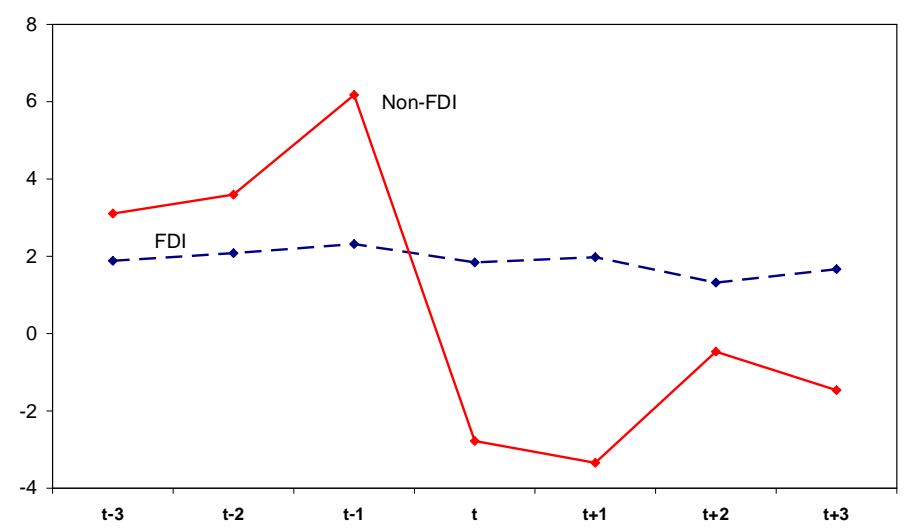

Note: Sudden Stops occur at $\mathrm{t}$ 
Table 2. Probability de occurrence of a Capital Boom

Dependent Variable FF

\begin{tabular}{|c|c|c|}
\hline & (1) & (2) \\
\hline $\mathrm{FF}_{\mathrm{t}-1}$ & $\begin{array}{c}12.514 \\
(4.29)^{\star \star \star}\end{array}$ & $\begin{array}{l}11.913 \\
(3.74)^{* * *}\end{array}$ \\
\hline CONTFF & $\begin{array}{l}5.617 \\
(3.15)^{\star \star *}\end{array}$ & $\begin{array}{l}4.282 \\
(2.22)^{\star *}\end{array}$ \\
\hline NonFDI & $\begin{array}{l}0.393 \\
(2.08)^{\star *}\end{array}$ & $\begin{array}{l}0.162 \\
(0.83)\end{array}$ \\
\hline RGDP & $\begin{array}{l}0.976 \\
(4.05)^{\star * *}\end{array}$ & $\begin{array}{l}0.655 \\
(2.51)^{\star \star}\end{array}$ \\
\hline CAD & $\begin{array}{c}1.091 \\
(4.20)^{\star \star \star}\end{array}$ & $(3.85)^{\star * *} 1.185$ \\
\hline TT & $\begin{array}{l}0.167 \\
(3.56)^{\star * *}\end{array}$ & $\begin{array}{l}0.154 \\
(1.52)\end{array}$ \\
\hline $\mathrm{ED} / \mathrm{X}$ & $\begin{array}{l}-6.440 \\
(4.81)^{\star * *}\end{array}$ & $(3.60)^{\star * *}$ \\
\hline $\mathrm{Rf}$ & & $\begin{array}{l}-0.629 \\
(1.93)^{*}\end{array}$ \\
\hline G7gdp & & $\begin{array}{l}-1.773 \\
(2.04)^{\star *}\end{array}$ \\
\hline Gov_Def & & $\begin{array}{c}-0.498 \\
(1.74)^{*}\end{array}$ \\
\hline $\mathrm{Rd}$ & & $\begin{array}{l}0.029 \\
(1.09)\end{array}$ \\
\hline
\end{tabular}

Observations

941

726

Average marginal effects (times 100) are reported for all regressors. Constants omitted. Figures in parenthesis are $z$ statistics with robust standard errors. All regressors are lagged one period, with the exception of CONTFF.

${ }^{*}$ significant at $10 \% ;{ }^{* *}$ significant at $5 \%$; ${ }^{* * *}$ significant at $1 \%$ 
Table 3. Probability of occurrence of a Sudden Stop Dependent Variable SS

\begin{tabular}{|c|c|c|c|c|c|}
\hline & (1) & (2) & (3) & (4) & (5) \\
\hline$\overline{F F_{t-1}}$ & $\begin{array}{l}9.148 \\
(4.25)^{\star \star \star}\end{array}$ & $\begin{array}{l}5.663 \\
(2.90)^{\star \star *}\end{array}$ & $\begin{array}{l}9.333 \\
(3.89)^{\star \star \star}\end{array}$ & $\begin{array}{l}8.638 \\
(3.89)^{\star \star \star}\end{array}$ & $\begin{array}{l}9.595 \\
(4.07)^{\star \star \star}\end{array}$ \\
\hline $\begin{array}{l}\text { CONTSS } \\
(2.02)^{*}\end{array}$ & $\begin{array}{l}2.798 \\
(2.33)^{\star *}\end{array}$ & $(1.70)^{*}(2.30)^{*}$ & 3.051 & $\begin{array}{l}2.611 \\
(2.26)^{\star \star}\end{array}$ & 2.340 \\
\hline NonFDI & $(3.18)^{\star \star \star} 0.369$ & $(4.54)^{\star \star \star} 0.594$ & $(3.45)^{0.491}$ & $(3.71)^{* \star * \star}=.553$ & $(4.31)^{\star \star \star} 0.627$ \\
\hline $\begin{array}{l}\text { CAD } \\
(1.24)\end{array}$ & $\begin{array}{l}0.472 \\
(3.60)^{\star \star \star}\end{array}$ & $\begin{array}{l}0.361 \\
(2.39)^{\star \star}\end{array}$ & $0.355(2.26)^{*}$ & 0.287 & $\begin{array}{l}0.192 \\
(1.77)^{*}\end{array}$ \\
\hline $\begin{array}{l}\text { EXR } \\
\text { bankcrises }\end{array}$ & & $\begin{array}{l}-0.250 \\
(0.61) \\
0.318 \\
(0.14)\end{array}$ & & & \\
\hline $\mathrm{ED} / \mathrm{X}$ & $(2.05)^{\star \star}$ & $\begin{array}{l}0.822 \\
(1.97)^{\star *}\end{array}$ & $0.943(2.21)^{*}$ & 0.967 & $\begin{array}{l}0.867 \\
(2.16)^{\star *}\end{array}$ \\
\hline TT & & & $\begin{array}{l}0.055 \\
(1.48)\end{array}$ & & \\
\hline dollarization & & & $\begin{array}{l}0.000 \\
(0.26)\end{array}$ & & \\
\hline openness & & & & $\begin{array}{l}0.017 \\
(0.82)\end{array}$ & \\
\hline Reserves & & & & $\begin{array}{l}-0.008 \\
(0.96)\end{array}$ & \\
\hline M2/GDP & & & & $\begin{array}{l}-0.022 \\
(0.69)\end{array}$ & \\
\hline $\mathrm{Rf}$ & & & & & $\begin{array}{l}0.011 \\
(0.06)\end{array}$ \\
\hline G7gdp & & & & & $\begin{array}{l}-0.704 \\
(1.19)\end{array}$ \\
\hline Gov_Def & & & & & $\begin{array}{l}0.061 \\
(0.47)\end{array}$ \\
\hline $\mathrm{Rd}$ & & & & & $\begin{array}{l}0.004 \\
(0.47)\end{array}$ \\
\hline Observations & 1070 & 893 & 875 & 958 & 856 \\
\hline
\end{tabular}


Table 4. Probit estimations with an extended period of capital boom

\begin{tabular}{|c|c|c|c|c|c|c|}
\hline $\begin{array}{l}\text { Explanatory } \\
\text { Variables }\end{array}$ & $\begin{array}{l}F F \\
(1)\end{array}$ & $\begin{array}{l}\text { FF } \\
(2)\end{array}$ & $\begin{array}{l}\text { FF } \\
(3)\end{array}$ & $\begin{array}{l}\text { SS } \\
(4)\end{array}$ & $\begin{array}{l}\text { SS } \\
(5)\end{array}$ & $\begin{array}{l}\text { SS } \\
(6)\end{array}$ \\
\hline $\mathrm{FF}_{\mathrm{t}-1}$ and $F F_{\mathrm{t}-2}$ & 2.2 & & & $7.0^{\star * *}-9.3^{\star \star *}$ & & \\
\hline$F F_{t-1}$ to $F F_{t-3}$ & & $-4.3^{\star \star}$ & & & $11.6^{\star \star *}-18.9^{\star \star \star}$ & \\
\hline$F F_{t-1}$ to $F F_{t-4}$ & & & -2.3 & & & $14.5^{*}-26.7^{*}$ \\
\hline CONTSS & $4.9^{\star * \star}$ & $4.8^{\star \star \star}$ & $5.1^{\star \star *}$ & $2.1^{*}-2.9^{* *}$ & $2.4^{*}-2.8^{* *}$ & $2.5^{\star *}-2.9^{\star \star}$ \\
\hline $\mathrm{NFDI}_{\mathrm{t}-1}$ & $0.4^{\star *}$ & $0.4^{* *}$ & $0.5^{\star \star \star}$ & $0.6^{\star \star \star}-0.8^{\star \star *}$ & $0.7^{\star \star \star}-0.8^{\star \star \star}$ & $0.7^{* *}-0.8^{* \star *}$ \\
\hline$C A D_{t-1}$ & $1.3^{\star \star \star}$ & $1.2^{\star \star \star}$ & $1.1^{\star * *}$ & $0.3^{\star *}-0.5^{\star \star *}$ & $0.3^{\star}-0.5^{\star \star \star}$ & $0.3^{* *}-0.5^{\star \star *}$ \\
\hline$E D / X_{t-1}$ & $-5.4^{\star \star \star}$ & $-4.9^{* * *}$ & $-5.3^{* * *}$ & $0.7^{*}-0.8^{*}$ & & \\
\hline $\mathrm{GDP}_{\mathrm{t}-1}$ & $0.6^{\star *}$ & $0.6^{* *}$ & $0.8^{\star * *}$ & & & \\
\hline G7gdp $p_{t-1}$ & $-1.7^{\star *}$ & $-1.5^{\star *}$ & & & & \\
\hline$R f_{t-1}$ & $-0.6^{\star *}$ & $-0.5^{\star}$ & $-0.9^{\star * *}$ & & & \\
\hline Gov_Def $_{t-1}$ & $0.5^{\star \star}$ & $0.7^{* \star *}$ & & & & \\
\hline$R d_{t-1}$ & & $0.0^{* *}$ & & & & \\
\hline
\end{tabular}


Table 5. Probit estimations with an extended period of capital boom,. 1990-2003

\begin{tabular}{|c|c|c|c|c|}
\hline $\begin{array}{l}\text { Explanatory } \\
\text { Variables }\end{array}$ & FF & $\begin{array}{l}\text { SS } \\
(1)\end{array}$ & SS & $\begin{array}{l}\text { SS } \\
(3)\end{array}$ \\
\hline $\mathrm{FF}_{\mathrm{t}-1}$ & $6.6^{* \star}$ & $\begin{array}{l}11.3^{\star \star \star}- \\
12.8^{\star \star \star}\end{array}$ & & \\
\hline$F F_{t-1}$ and $F F_{t-2}$ & & & $14.6^{\star *}-20.8^{\star \star *}$ & \\
\hline$F F_{t-1}-F F_{t-3}$ & & & & $25.5^{*}-28.1^{*}$ \\
\hline CONT & $5.8^{\star *}$ & $6.0^{*}-15.1^{* *}$ & $6.7^{* \star}-14.2^{\star \star \star}$ & $7.5^{\star *}-14.0^{* *}$ \\
\hline$N F_{t-1}$ & & $0.6^{\star *}-0.7^{\star *}$ & $0.8^{\star \star \star}-0.9^{* \star *}$ & $0.8^{* *}-1.1^{* * *}$ \\
\hline $\operatorname{CAD}_{\mathrm{t}-1}^{\mathrm{a}}$ & $1.3^{\star * \star}$ & & & \\
\hline $\mathrm{RGDP}_{\mathrm{t}-1}$ & $1.2^{* \star \star}$ & & & \\
\hline dollarization $_{\mathrm{t}-1}$ & & $0.02^{* *}$ & & \\
\hline
\end{tabular}

Table reports significant marginal effects (times 100) only. ${ }^{a}$ CAD was used in the boom equation only. ${ }^{*}$ significant at $10 \%$; ${ }^{* *}$ significant at $5 \% ;{ }^{* * *}$ significant at $1 \%$ 
Table 6. Some Robustness Exercises for Capital Boom Estimations

\begin{tabular}{|c|c|c|c|}
\hline $\begin{array}{l}\text { Explanatory } \\
\text { Variables }\end{array}$ & $3 \%$ & $7 \%$ & FFgross $^{a}$ \\
\hline$F F_{t-1}$ & $10.5^{\star \star \star}$ & $11.9^{* \star *}$ & $10.5^{\star \star \star}$ \\
\hline CONTFF & $5.7^{* \star}$ & & $4.1^{*}$ \\
\hline$N F_{t-1}$ & & & $0.4^{* *}$ \\
\hline $\mathrm{CAD}_{\mathrm{t}-1}$ & $1.1^{\star \star \star}$ & $1.1^{\star \star \star}$ & $1.1^{* \star *}$ \\
\hline $\mathrm{GDP}_{\mathrm{t}-1}$ & $0.7^{* \star}$ & $0.5^{\star \star}$ & \\
\hline$E D / X_{t-1}$ & $-5.9^{* \star *}$ & $-4.5^{\star \star *}$ & $-5.6^{* * *}$ \\
\hline$R f_{t-1}$ & $-0.9^{* *}$ & & \\
\hline G7gdp $p_{t-1}$ & $-2.7^{* \star *}$ & & $-2.1^{\star \star}$ \\
\hline Gov_Def & & $-0.5^{\star \star}$ & \\
\hline$R d_{t-1}$ & $0.05^{*}$ & & \\
\hline
\end{tabular}


Table 7. Some Robustness Exercises for Sudden Stop Estimations

\begin{tabular}{|c|c|c|c|c|}
\hline $\begin{array}{l}\text { Explanatory } \\
\text { Variables }\end{array}$ & $3 \%$ & $7 \%$ & SSgross $^{a}$ & SSgdp \\
\hline $\mathrm{FF}_{\mathrm{t}-1}$ & $\begin{array}{l}10.5^{\star \star \star}- \\
12.9^{\star \star \star}\end{array}$ & $5.2^{\star \star \star}-7.5^{\star \star \star}$ & $\begin{array}{l}11.7^{\star * \star}- \\
14.8^{\star * *}\end{array}$ & $5.1^{* \star *}-6.2^{* \star *}$ \\
\hline CONTSS & $3.1^{\star \star}-4.0^{\star \star \star}$ & & & $1.6^{\star}-2.6^{\star \star \star}$ \\
\hline$N F_{t-1}$ & $0.4^{\star \star \star}-0.7^{\star \star \star}$ & $0.3^{\star \star \star}-0.3^{\star \star \star}$ & $0.1^{* *}-0.3^{* \star *}$ & $0.1^{*}-0.2^{\star \star \star}$ \\
\hline $\operatorname{CAD}_{\mathrm{t}-1}{ }^{\mathrm{a}}$ & $0.3^{*}-0.4^{* * *}$ & $0.2^{* * *}-0.3^{* *}$ & $0.5^{\star * *}-0.6^{\star * *}$ & $0.2^{* *}-0.3^{* * *}$ \\
\hline$E D / X_{t-1}$ & $0.9^{*}-1.0^{* *}$ & $0.5^{\star *}-0.7^{* *}$ & & $0.5^{\star}-0.8^{\star \star *}$ \\
\hline$E X R_{t-1}$ & & $-0.4^{*}--0.6^{* *}$ & & \\
\hline Dollarization $_{\mathrm{t}-1}$ & & $0.0^{* *}-0.0^{* * *}$ & & $0.0^{* *}$ \\
\hline Reserves $_{\mathrm{t}-1}$ & & $\begin{array}{c}-0.02^{* *}-- \\
0.02^{* * *}\end{array}$ & & \\
\hline $\mathrm{Rf}_{\mathrm{t}-1}$ & & & & $0.3^{* *}$ \\
\hline $\mathrm{Rd}_{\mathrm{t}-1}$ & & & & $0.0^{*}-0.0^{* *}$ \\
\hline
\end{tabular}


Table 8. Probit Estimations on SSgdp with an extended period of Capital Boom.

\begin{tabular}{|c|c|c|c|}
\hline $\begin{array}{l}\text { Explanatory } \\
\text { Variables }\end{array}$ & $\begin{array}{l}\text { SSgdp } \\
\text { (1) }\end{array}$ & $\begin{array}{l}\text { SSgdp } \\
\text { (2) }\end{array}$ & $\begin{array}{l}\text { SSgdp } \\
\text { (3) }\end{array}$ \\
\hline $\mathrm{FF}_{\mathrm{t}-1}$ y $\mathrm{FF}_{\mathrm{t}-2}$ & $5.5^{\star \star \star}-9.4^{\star \star \star}$ & & \\
\hline$F F_{t-1}-F F_{t-3}$ & & $8.0^{* \star *}-18.9^{* \star *}$ & \\
\hline$F F_{t-1}-F F_{t-4}$ & & & $20.1^{\star \star *}-34.5^{\star \star \star}$ \\
\hline CONTSS & $1.6^{*}-2.3^{\star *}$ & $1.6^{*}-2.7^{\star *}$ & $1.6^{*}-2.5^{\star * *}$ \\
\hline$N F_{t-1}$ & $0.2^{* * *}-0.3^{* * *}$ & $0.3^{* * *}-0.7^{* \star *}$ & $2.8^{* *}-3.2^{\star *}$ \\
\hline $\mathrm{CAD}_{\mathrm{t}-1}$ & $0.2^{*}-0.3^{\star * *}$ & $0.2^{* *}-0.4^{* *}$ & $0.2^{*}-0.4^{* *}$ \\
\hline$E D / X_{t-1}$ & $0.5^{\star}-0.8^{\star *}$ & $0.6^{* *}-0.7^{* \star *}$ & $0.5^{\star *}-0.6^{*}$ \\
\hline$R d_{t-1}$ & & & $0.0^{\star \star}$ \\
\hline
\end{tabular}


Table 9. Probability of occurrence of a Sudden Stop including a "signal" of the Current Account Deficit

\begin{tabular}{|c|c|c|c|c|c|c|c|}
\hline SSgross & $\begin{array}{l}(1) \\
\text { SS }\end{array}$ & $\begin{array}{l}\text { (2) } \\
\text { SSgdp }\end{array}$ & $\begin{array}{l}(3)^{\mathrm{a}} \\
\text { SSgross }\end{array}$ & (4) & $\mathrm{SS}^{(5)}$ & $(6)^{\mathrm{a}}$ SSgdp & \\
\hline $\mathrm{S} \mathrm{CAD}_{\mathrm{t}-1}$ & $\begin{array}{l}1.867 \\
(0.96)\end{array}$ & $\begin{array}{l}0.946 \\
(0.73)\end{array}$ & $\begin{array}{l}4.868 \\
(1.88)^{\star}\end{array}$ & $\begin{array}{l}4.070 \\
(2.17)^{* *}\end{array}$ & $\begin{array}{ll} & 2.359 \\
* & (181)^{*}\end{array}$ & $\begin{array}{l}8.930 \\
(370)^{* * *}\end{array}$ & \\
\hline $\mathrm{FF}_{\mathrm{t}-1}$ & $\begin{array}{l}8.204 \\
(3.80)^{\star * *}\end{array}$ & $\begin{array}{l}4.880 \\
(3.15)^{* \star *}\end{array}$ & $\begin{array}{l}14.699 \\
*(5.57)^{* * *}\end{array}$ & $\begin{array}{l}8.716 \\
(3.92)^{\star \star \star}\end{array}$ & $\begin{array}{l}5.538 \\
* * \\
(3.31)^{* *}\end{array}$ & $\begin{array}{l}15.873 \\
(5.91)^{* * *}\end{array}$ & \\
\hline CONTSS & $\begin{array}{l}3.137 \\
(2.42)^{\star *}\end{array}$ & 2.184 & $\begin{array}{c}0.132 \\
2.42)^{* *}\end{array}$ & (2.10) & $\begin{array}{c}2.307 \\
(2.51)^{\star *}\end{array}$ & $\begin{array}{c}0.182 \\
(2.47)^{\star *}\end{array}$ & $(0.13)$ \\
\hline $\begin{array}{l}\text { NonFDI }_{t-1} \\
(2.26)^{\star *}\end{array}$ & $\begin{array}{l}0.493 \\
(3.77)^{\star \star \star}\end{array}$ & $\begin{array}{l}0.189 \\
(2.10)^{\star *}\end{array}$ & $\begin{array}{l}0.098 \\
(2.14)^{\star \star}\end{array}$ & 0.596 & $\begin{array}{r}0.227 \\
(4.32)^{\star \star \star}\end{array}$ & $\begin{array}{c}0.113 \\
(2.31)^{\star *}\end{array}$ & \\
\hline $\mathrm{CAD}_{\mathrm{t}-1}$ & $\begin{array}{l}0.268 \\
(1.62)\end{array}$ & $\begin{array}{l}0.155 \\
(1.42)\end{array}$ & $\begin{array}{l}0.310 \\
(1.72)^{*}\end{array}$ & & & & \\
\hline $\mathrm{ED} / \mathrm{X}_{\mathrm{t}-1}$ & $(2.12)^{\star * *}$ & & $\begin{array}{l}.726 \\
3.16)^{\star \star \star}\end{array}$ & & $\begin{array}{ll}0.989 & 0 \\
(2.59)^{\star * \star}\end{array}$ & $\begin{array}{l}0.842 \\
(3.64)^{\star \star \star}\end{array}$ & \\
\hline Observations & 1006 & 1007 & 1067 & 1006 & 1007 & 1067 & \\
\hline
\end{tabular}


Table 10. Probability of occurrence of a Sudden Stop including a "signal" of the Current Account Deficit

\begin{tabular}{|c|c|c|c|c|c|c|c|}
\hline SSgross & $\begin{array}{l}(1) \\
\text { SS }\end{array}$ & $\begin{array}{l}\text { (2) } \\
\text { SSgdp }\end{array}$ & $\begin{array}{l}(3)^{\mathrm{a}} \\
\text { SSgross }\end{array}$ & (4) & $\mathrm{SS}^{(5)}$ & $(6)^{\mathrm{a}}$ SSgdp & \\
\hline $\bar{S}^{2 C A D}{ }_{t-1}$ & $\begin{array}{l}0.661 \\
(0.34)\end{array}$ & $\begin{array}{l}1.169 \\
(0.79)\end{array}$ & $\begin{array}{l}4.080 \\
(1.45)\end{array}$ & $\begin{array}{l}2.636 \\
(1.20)\end{array}$ & $\begin{array}{l}2.480 \\
(1.53)\end{array}$ & $\begin{array}{l}6.923 \\
(2.45)^{\star *}\end{array}$ & \\
\hline $\mathrm{FF}_{\mathrm{t}-1}$ & $\begin{array}{l}8.292 \\
(3.87)^{\star \star \star}\end{array}$ & $\begin{array}{l}4.880 \\
(3.16)^{\star \star \star}\end{array}$ & $\begin{array}{l}14.783 \\
* * 59)^{* *}\end{array}$ & $\begin{array}{l}9.409 \\
(4.17)^{*}\end{array}$ & )$^{\star \star \star} \begin{array}{l}5.821 \\
(3.41)^{\star \star}\end{array}$ & $\begin{array}{ll} & 15.107 \\
\star \star \star * & (5.44)^{\star \star *}\end{array}$ & \\
\hline CONTSS & $\begin{array}{l}3.094 \\
(2.41)^{\star \star}\end{array}$ & 2.192 & $\begin{array}{l}0.160 \\
2.43)^{\star \star}\end{array}$ & $\begin{array}{l}3.381 \\
(0.12)\end{array}$ & $\begin{array}{c}2.342 \\
(2.54)^{* *}\end{array}$ & $\begin{array}{l}0.683 \\
(2.49)^{* *}\end{array}$ & $(0.49)$ \\
\hline $\begin{array}{l}\text { NonFDI }_{t-1} \\
(2.94)^{\star * *}\end{array}$ & $\begin{array}{l}0.484 \\
(3.77)^{\star \star *}\end{array}$ & $\begin{array}{l}0.189 \\
(2.20)^{\star *}\end{array}$ & $\begin{array}{l}0.093 \\
* \\
(2.03)^{* *}\end{array}$ & $\begin{array}{r}0.644 \\
\times \quad 0\end{array}$ & $\begin{array}{r}0.245 \\
(4.54)^{\star * \star}\end{array}$ & $\begin{array}{l}0.388 \\
(2.54)^{* \star}\end{array}$ & \\
\hline$C A D_{t-1}$ & $\begin{array}{l}0.351 \\
(2.31)^{\star *}\end{array}$ & 0.168 & $\begin{array}{l}0.420 \\
1.64)^{*}\end{array}$ & $(2.47)^{\star \star}$ & & & \\
\hline$E D / X_{t-1}$ & $(2.07)^{* *} 0.7 \varepsilon$ & & $\begin{array}{l}3.717 \\
3.22)^{\star \star \star}\end{array}$ & & $\begin{array}{l}1.033 \\
(2.70)^{\star \star \star}\end{array}$ & $\begin{array}{l}0.858 \\
(3.67)^{\star * *}\end{array}$ & \\
\hline Observations & 1006 & 1007 & 1067 & 1006 & 1007 & 1067 & \\
\hline
\end{tabular}


Table 11. Rivers and Vuong (1988) test for the null hypothesis that capital boom and sudden stop errors are not correlated in expression (4)

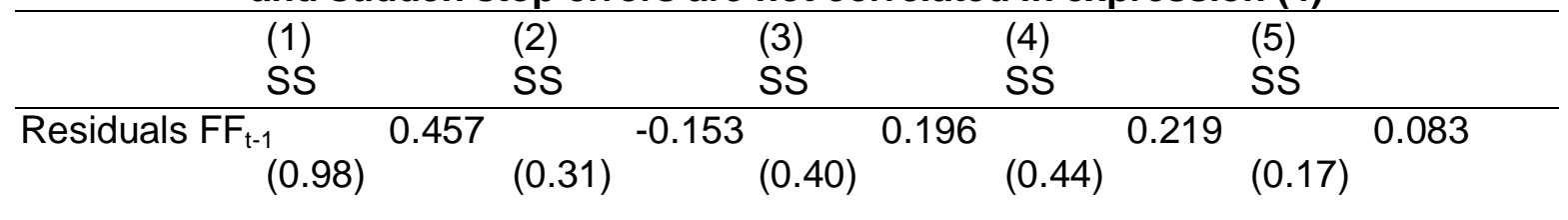

z statistics are in parenthesis. The estimations of Table 3 are repeated including the residuals of capital boom equation (2) in Table 2. 


\section{Appendix}

\section{List of emerging countries}

Argentina, Bangladesh, Barbados, Belize, Bolivia, Brazil, Chile, China, Colombia, Cote d'Ivoire, Costa Rica, Ecuador, Egypt, El Salvador, Philippines, Guatemala, Hungary, India, Indonesia, Iran, Jamaica, Jordan, Kenya, Korea, Mali, Malaysia, Malta, Morocco, Mauritius, Mexico, Nigeria, Peru, Pakistan, Panama, Paraguay, Poland, Dominican

Republic, South Africa, Thailand, Tunisia, Turkey, and Uruguay.

\section{Capital Booms (FF) 1976-2003 ${ }^{a}$}

\begin{tabular}{l|llllllllllll}
\hline 1976 & BRA & POL & MAR & TUN & & & & & & & \\
1977 & CRI & MAR & TUN & & & & & & & \\
1978 & BOL & BRA & CRI & CIV & PAK & PRY & BGD & SLV & JOR & KEN & MAR & TUN \\
1979 & CRI & CIV & NGA & PRY & URY & KEN & MLI & PAN & EGY & & \\
1980 & CHI & CRI & CIV & ECU & PRY & URY & BGD & DOM & KEN & MLI & \\
1981 & BOL & CHI & CIV & MEX & NGA & PRY & URY & BGD & BRB & EGY & \\
1982 & CRI & IDN & NGA & PER & URY & EGY & & & & & \\
1983 & IDN & NGA & & & & & & & & & \\
1984 & JAM & & & & & & & & & & \\
1985 & & & & & & & & & & & \\
1986 & & & & & & & & & & & \\
1987 & & & & & & & & & & & \\
1988 & MUS & & & & & & & & & & \\
1989 & KEN & & & & & & & & & & \\
1990 & MUS & & & & & & & & & \\
1991 & IRN & MEX & THA & JOR & & & & & & \\
1992 & IRN & MYS & MEX & & & & & & & \\
1993 & ARG & HUN & IRN & MYS & MEX & PAK & TUR & TUN & & & \\
1994 & ARG & CHL & CHN & PAR & PAK & PHL & THL & MLT & TUN & & \\
1995 & BRA & CHN & COL & HUN & IDN & MYS & PER & PHL & POL & THA & \\
1996 & BRA & CHI & CHN & COL & IDN & KOR & MYS & PAK & PER & PHL & THA & \\
1997 & ARG & BOL & CHI & COL & PER & PHL & SLV & PAN & ZAF & & \\
1998 & ARG & BOL & HUN & POL & SLV & GTM & MLT & PAN & & & \\
1999 & ARG & BOL & HUN & POL & DOM & MLT & PAN & & & & \\
2000 & HUN & POL & BRB & DOM & GTM & JAM & MLI & MUS & & & \\
2001 & BRB & BLZ & DOM & GTM & JAM & PAN & & & & & \\
2002 & BLZ & GTM & JAM & & & & & & & \\
2003 & HUN & BRB & BLZ & SLV & MLI & & & & & & \\
\hline
\end{tabular}

${ }^{\mathrm{a}}$ We use country abbreviations from World Development Indicator. 
Sudden Stops (SS) 1977-2003 ${ }^{\mathrm{a}}$

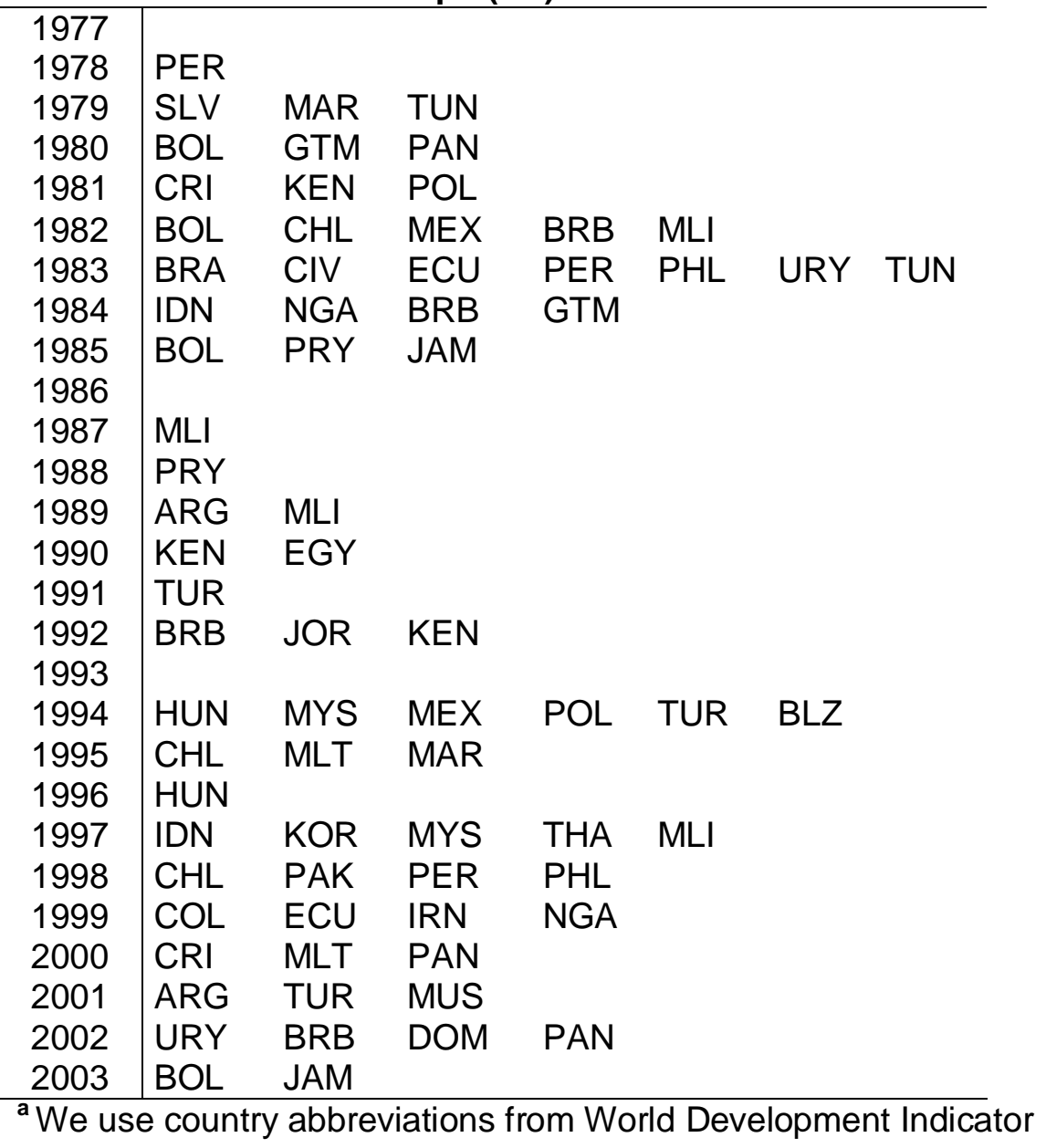

\section{Definition of Variables}

\begin{tabular}{|l|l|l|}
\hline Variable & Definition & Source \\
\hline Capital Flows & $\begin{array}{l}\text { Financial account deflated } \\
\text { by the US consumer price } \\
\text { index, 2000=100 }\end{array}$ & $\begin{array}{l}\text { International Financial } \\
\text { Statistics (IFS) }\end{array}$ \\
\hline GDP & Gross domestic product & $\begin{array}{l}\text { World Development } \\
\text { Indicators (WDI) }\end{array}$ \\
\hline $\begin{array}{l}\text { Current Account to GDP, } \\
C A D\end{array}$ & Measured as deficit & WDI \\
\hline $\begin{array}{l}\text { Non-FDI flows to GDP, } \\
\text { NonFDI }\end{array}$ & $\begin{array}{l}\text { Sum of portfolio flows, IFS, WDI } \\
\text { other investment and } \\
\text { financial derivatives, as } \\
\text { share of GDP }\end{array}$ \\
\hline $\begin{array}{l}\text { External Debt to exports } \\
\text { ratio, ED/X }\end{array}$ & $\begin{array}{l}\text { Ratio of public and private } \\
\text { external debt (long- and } \\
\text { short-term) to exports of } \\
\text { goods and services }\end{array}$ & \\
\hline Ratio of export to import & WDI \\
\hline Terms of Trade, TT & \begin{tabular}{l} 
Ration \\
\hline
\end{tabular} &
\end{tabular}




\begin{tabular}{|c|c|c|}
\hline & $\begin{array}{l}\text { deflators, both obtained } \\
\text { from real and nominal } \\
\text { trade data. }\end{array}$ & \\
\hline Real Exchange Rate, $R E R$ & $\begin{array}{l}\text { Ratio of US consumer } \\
\text { price index multiplied by } \\
\text { nominal exchange rate to } \\
\text { domestic consumer price } \\
\text { index }\end{array}$ & IFS \\
\hline $\begin{array}{l}\text { Foreign real interest rate, } \\
R f\end{array}$ & $\begin{array}{l}\text { three-month US-dollar } \\
\text { LIBOR, deflated by US } \\
\text { consumer prices }\end{array}$ & IFS \\
\hline $\begin{array}{l}\text { Domestic real interest rate, } \\
\text { Rd }\end{array}$ & $\begin{array}{l}\text { deposit money market rate } \\
\text { adjusted for consumer } \\
\text { price inflation }\end{array}$ & IFS \\
\hline $\begin{array}{l}\text { GDP growth of } \\
\text { countries, G7gr }\end{array}$ & $\begin{array}{l}\text { Simple average of annual } \\
\text { growth rate of real GDP of } \\
\text { G7 countries }\end{array}$ & WDI \\
\hline Fiscal deficit, Gov_Def & Measured as deficit & IFS \\
\hline Banking Crises, bankcrises & $\begin{array}{l}\text { Binary variable taking } \\
\text { value } 1 \text { during a year of } \\
\text { banking crises }\end{array}$ & $\begin{array}{l}\text { Caprio and Klingebiel } \\
(2003)\end{array}$ \\
\hline $\begin{array}{l}\text { Exchange Rate Regime, } \\
\text { EXR }\end{array}$ & $\begin{array}{lr}1-5 \text { index according } & \text { to } \\
\text { exchange rate rigidity. } & 5 \\
\text { indicates a fixed regime } & \end{array}$ & $\begin{array}{ll}\text { Levy-Yeyati } & \text { and } \\
\text { Sturzenegger (2005) } & \end{array}$ \\
\hline Openness & $\begin{array}{l}\text { Exports plus imports as a } \\
\text { share of GDP }\end{array}$ & WDI \\
\hline Dollarization & $\begin{array}{l}\text { External liabilities of } \\
\text { financial sector as a } \\
\text { percentage of money }\end{array}$ & IFS \\
\hline Reserves & International Reserves & IFS \\
\hline $\mathrm{M} 2$ to $\mathrm{GDP}, M 2 / G D P$ & $\begin{array}{l}\text { M2 as a percentage of } \\
\text { GDP }\end{array}$ & IFS \\
\hline
\end{tabular}

